\title{
Analysis of key issues in electric-hydrogen coupled operation
}

\author{
Wang Xiaochen ${ }^{1}$, Lv Mengxuan ${ }^{1}$, Fu Yifan ${ }^{2}$ \\ ${ }^{1}$ State Grid Energy Research Institute Co., Ltd., Changping District, Beijing 102209 \\ ${ }^{2}$ North China Electric Power University, Baoding, Hebei 071000
}

\begin{abstract}
This paper conducts an in-depth analysis of the electricity-hydrogen coupling under the highpermeability renewable energy scenario, and further proposes that the production of hydrogen from electrolyzed water is a key link in the electricity-hydrogen coupling under the high-permeability renewable energy scenario. Analysis of key issues in technical routes and other aspects, and finally put forward development suggestions for the development of hydrogen energy under the scenario of high-permeability renewable energy.
\end{abstract}

\section{Introduction}

The greenhouse effect brought by carbon dioxide is becoming more and more significant, posing a great threat to the earth's environment and human life. Countries in the world are embarking on the transformation of energy structure. Hydrogen is a secondary energy that has developed rapidly in recent years. It has the advantages of high calorific value, wide sources, easy storage, clean and low-carbon applications, and can be widely used in industries, transportation, household energy, aerospace and other fields, and its development prospects broad ${ }^{[1]}$.

From the perspective of various aspects of the hydrogen energy industry, domestic and foreign researches have been conducted on hydrogen energy development strategies and technical characteristics. Literature [1] analyzes the prominent problems faced by the development of various links in the hydrogen energy and fuel cell automobile industry, and proposes that the development of the hydrogen energy industry should not only focus on the development of scale, but also the highquality development of my country's hydrogen energy industry, and put forward relevant Development proposals. Literature [2] outlines the development of hydrogen generators and hydrogen fuel cell vehicles based on hydrogen-electric coupling, and believes that hydrogen fuel cell vehicles are the main direction of hydrogen power generation, but they still face many challenges. In summary, the development of hydrogen energy has been studied in various links and from many angles. Renewable energy with high penetration rate in the future is the main scenario for energy development, which has an important impact on the coupled operation of electricity and hydrogen.
Aiming at the problem of electricity-hydrogen coupling operation, this paper conducts an in-depth analysis of electricity-hydrogen coupling under the highpermeability renewable energy scenario, and further proposes that hydrogen production from electrolysis of water is the key link of electricity-hydrogen coupling under the high-permeability renewable energy scenario. Subsequently, the analysis of key issues in the technical route and other aspects of hydrogen production from electrolysis of water was carried out, and finally, the development suggestions for the development of hydrogen energy under the high-permeability renewable energy scenario were put forward in terms of institutional mechanisms.

\section{Electric-hydrogen coupling operation analysis}

According to the classification of sources, hydrogen energy can be divided into green hydrogen, gray hydrogen, blue hydrogen and waste hydrogen. One of the key issues facing the development of hydrogen energy in the future is the heavy dependence on traditional fossil energy. According to statistics, about $96 \%$ of global hydrogen energy comes from fossil energy hydrogen production and industrial by-product hydrogen ${ }^{[4]}$. Therefore, from the perspective of the whole process, even if the large-scale promotion and application of hydrogen energy is realized, the replacement of traditional fossil energy and the deep decarbonization are still unable to be realized ${ }^{[1-2]}$. The high-permeability renewable energy brings an important opportunity for the development of green hydrogen and helps hydrogen energy achieve the dual sustainable development of resources and the environment.

\footnotetext{
* Corresponding author: wangxiaochen@sgeri.sgcc.com.cn
} 
Table 1. Comparison of various types of hydrogen

\begin{tabular}{|c|c|c|c|c|}
\hline Source & Green Hydrogen & Gray Hydrogen & Blue Hydrogen & Waste Hydrogen \\
\hline Cost (yuan/kg) & 30 & Fossil energy & $\begin{array}{c}\text { Fossil energy with } \\
\text { CO }_{2} \text { capture }\end{array}$ & $\begin{array}{c}\text { Industrial by- } \\
\text { product hydrogen }\end{array}$ \\
\hline Percentage & $5 \%$ & 10 & 17 & 21 \\
\hline Purity & High & $45 \%$ & $15 \%$ & $35 \%$ \\
\hline
\end{tabular}

Note: The electricity price used in the calculation of green hydrogen cost is 0.4 yuan/kwh

Renewable energy with high permeability is conducive to promoting the deep coupling of "electricity-hydrogen" systems. The development of electric-hydrogen coupling technology promotes the large-scale development of green hydrogen, reduces the dependence of hydrogen energy on fossil energy, and realizes the dual sustainable development of resources and the environment key. In terms of specific links, it mainly includes related technologies such as hydrogen production by electrolysis of water, hydrogen storage, hydrogen transmission, and new energy.

\subsection{Analysis of hydrogen production by electrolysis of water}

Hydrogen production by electrolysis of water uses electrochemical reactions that occur on electrodes to decompose water molecules into hydrogen and oxygen. It is the main source of green hydrogen and is expected to become an effective supply of hydrogen energy around 2030. Hydrogen production by electrolysis of water is the key to electricity-hydrogen coupling. Its large-scale and low-cost development is of great significance to hydrogen energy and power systems.

From the perspective of hydrogen energy, it is the key to reduce the dependence on fossil energy from the source of hydrogen energy production and realize the dual sustainable development of resources and the environment, and the high purity of hydrogen produced is important for high-purity hydrogen markets such as hydrogen fuel cell vehicles. High adaptability is the main direction for future hydrogen production technology development. From the perspective of the power system, the electrolyzed hydrogen production device can be used as a new type of flexible resource on the load side, which will help expand the system load demand, improve the system flexibility, and is a new means to enhance the capacity of renewable energy consumption.

\subsection{Hydrogen storage analysis}

From the perspective of electricity-hydrogen coupling under the high-permeability renewable energy scenario, hydrogen energy storage can provide power systems with multiple types of services such as peak shaving, frequency modulation, and cross-season energy storage by cooperating with electrolysis of hydrogen production technology, especially Renewable energy can be used to electrolyze water into hydrogen (and oxygen) during low trough periods, and store hydrogen; during peak periods, the stored hydrogen can be converted into electrical energy through fuel cells and other means for transmission to the Internet. Therefore, it helps to absorb renewable energy and reduce carbon emissions from traditional fossil energy.

However, from the perspective of the entire link of "electricity-hydrogen-electricity", the conversion efficiency of "electricity-hydrogen-electricity" based on hydrogen energy storage is generally lower, and there are fewer cross-season peak shaving practices in the power system, so compared with electrochemical energy storage Other types of energy storage, such as physical energy storage, are currently lacking in large-scale application scenarios in power systems. They can be used as backup power sources in the near future.

\subsection{Hydrogen analysis}

Due to the unbalanced distribution of hydrogen sources such as renewable energy electrolysis of water hydrogen, fossil energy hydrogen production, and industrial byproduct hydrogen among regions, as the demand for hydrogen energy continues to increase, large-scale hydrogen storage and transportation will become inevitable ${ }^{[1]}$, hydrogen transmission Technology development will largely determine the future development speed and pattern of the hydrogen energy industry.

Depending on the state of hydrogen, hydrogen is mainly transported in three forms: high-pressure gas, lowtemperature liquid, and solid materials ${ }^{[5]}$. Among them, high-pressure gas transportation mainly includes longtube trailer transportation and pipeline transportation. The transportation distance is one of the important factors that affect the economy of the transportation method. The transportation cost varies with the transportation distance in different hydrogen transportation methods, so the suitable transportation methods for different distances are different. It is estimated that the pipeline transportation cost is the lowest in the range of $0 \sim 1000 \mathrm{~km}$. Considering the long pipeline construction period, the recent long-tube trailer transportation and low-temperature liquid transportation are compared. When the transportation distance is within $250 \mathrm{~km}$, the long-tube trailer transportation cost is lower, the low temperature liquid transportation of more than $250 \mathrm{~km}$ has more cost advantages. 
Table 2. Comparison of hydrogen transmission technologies

\begin{tabular}{|c|c|c|}
\hline Type & Advantage & Disadvantage \\
\hline $\begin{array}{l}\text { Long tube } \\
\text { trailer }\end{array}$ & $\begin{array}{l}\text { Short-distance } \\
\text { transportation } \\
\text { has low cost, } \\
\text { flexible } \\
\text { adjustment of } \\
\text { transportation } \\
\text { capacity, and } \\
\text { mature } \\
\text { development }\end{array}$ & $\begin{array}{l}\text { The transportation } \\
\text { cost increases } \\
\text { rapidly with the } \\
\text { increase of the } \\
\text { transportation } \\
\text { distance, the } \\
\text { transportation } \\
\text { distance is shorter } \\
\text { and the } \\
\text { transportation } \\
\text { volume is lower }\end{array}$ \\
\hline Pipeline & $\begin{array}{c}\text { Suitable for } \\
\text { large-scale and } \\
\text { long-distance } \\
\text { transportation, } \\
\text { safe and reliable } \\
\end{array}$ & $\begin{array}{l}\text { The initial } \\
\text { investment cost is } \\
\text { high, the flexibility } \\
\text { of capacity } \\
\text { adjustment is poor }\end{array}$ \\
\hline $\begin{array}{c}\text { Cryogenic } \\
\text { liquid }\end{array}$ & $\begin{array}{l}\text { The long- } \\
\text { distance } \\
\text { transport } \\
\text { efficiency is } \\
\text { high, the } \\
\text { transport } \\
\text { capacity } \\
\text { adjustment is } \\
\text { flexible, and the } \\
\text { overall cost is } \\
\text { low }\end{array}$ & $\begin{array}{c}\text { Higher } \\
\text { requirements on } \\
\text { equipment, } \\
\text { processes, and } \\
\text { energy. Hydrogen } \\
\text { liquefaction } \\
\text { requires a large } \\
\text { one-time } \\
\text { investment and } \\
\text { large energy loss }\end{array}$ \\
\hline
\end{tabular}

\subsection{New energy vehicles}

New energy vehicles will be the most important field of hydrogen energy applications in the near future. From the perspective of "hydrogen-electricity" coupling, hydrogen fuel cell vehicles and pure electric vehicles are both new energy vehicles. The functions of transportation and travel requirements overlap, and the development of hydrogen fuel cell vehicles needs to be studied and judged from the overall perspective of new energy vehicles ${ }^{[1,2]}$.

Currently, hydrogen fuel cell vehicles and pure electric vehicles show good complementary characteristics in application scenarios due to their respective technical performance limitations. Hydrogen fuel cell vehicles can make up for the short range of pure electric vehicles, slow charging speed, and low temperature tolerance ${ }^{[6]}$, while pure electric vehicles have low cost and complete infrastructure ${ }^{[7]}$. In the long run, with the advancement of hydrogen fuel cell vehicles and pure electric vehicles, their performance in the new energy market will gradually become homogeneous. As the current market for pure electric vehicles is large and has a strong first-mover advantage, technological progress and the speed of infrastructure construction are important factors that determine the future development prospects of hydrogen fuel cell vehicles.

\section{Analysis of key issues in electric- hydrogen coupled operation}

In summary, the electric-hydrogen coupled operation is the key to improving the absorption capacity of renewable energy and realizing deep decarbonization. However, there are still many problems that need to be analyzed and judged.

\subsection{The cost of hydrogen production from electrolyzed water}

The current bottleneck for the development of hydrogen production from electrolyzed water is the high $\cos ^{t^{[8]}}$, of which electricity price costs account for about $70 \%$. According to calculations, it is economically competitive when the electricity price for hydrogen production by electrolysis of water needs to be reduced to about 0.15 yuan/kw h. Therefore, many current studies advocate the use of renewable energy waste power for hydrogen production, relying on low-cost waste power to reduce hydrogen production costs while increasing the level of renewable energy utilization ${ }^{[9]}$. According to calculations, from an overall point of view, the use of waste water, waste wind, and waste electricity to produce hydrogen from water electrolysis has certain potential.

Table 3. Electricity curtailment and hydrogen production potential and distribution in 2019

\begin{tabular}{|c|c|c|c|}
\hline & $\begin{array}{c}\text { Abandon } \\
\text { Water }\end{array}$ & $\begin{array}{c}\text { Abandon } \\
\text { Wind }\end{array}$ & $\begin{array}{c}\text { Abandon } \\
\text { Light }\end{array}$ \\
\hline $\begin{array}{c}\text { Resources(100 million } \\
\text { kwh) }\end{array}$ & 300 & 169 & 46 \\
\hline $\begin{array}{c}\text { Hydrogen production } \\
\left.\text { potential (100 million } \mathrm{m}^{3}\right)\end{array}$ & 60 & 34 & 9 \\
\hline $\begin{array}{c}\text { Major distribution areas of } \\
\text { curtailment }\end{array}$ & $\begin{array}{c}\text { Sichuan, } \\
\text { Yunnan, } \\
\text { etc. }\end{array}$ & $\begin{array}{c}\text { Xinjiang, } \\
\text { Gansu, } \\
\text { Inner } \\
\text { Mongolia, } \\
\text { etc. }\end{array}$ & $\begin{array}{c}\text { Xinjiang, } \\
\text { Gansu, } \\
\text { etc. }\end{array}$ \\
\hline
\end{tabular}

However, from the perspective of the distribution of renewable energy curtailment, it is mainly concentrated in large renewable energy provinces such as the northwest and southwest, and is generally far away from the main hydrogen energy demand regions. Considering the current hydrogen energy storage and transportation efficiency and cost, it is not large-scale, Long-distance transportation technology and infrastructure conditions.

In addition, the curtailment of electricity has the characteristics of randomness, small amount, and high volatility ${ }^{[10]}$, which has led to a very low utilization rate of hydrogen production equipment from electrolyzed water, especially as the utilization rate of renewable energy in my country has increased year by year. The scale of hydrogen production by electrolysis of water is always limited, so it is not feasible to produce large-scale hydrogen from waste electricity.

In the future, the development of hydrogen production by electrolysis of water will inevitably use the main unit of renewable energy power generation on a large scale on the basis of making full use of waste power resources. Therefore, its large-scale and commercial development depends on its own technological progress and scale effects. Low cost hydrogen production. 


\subsection{Selection of technical route for hydrogen production by electrolysis of water}

According to the type of electrolyzer, hydrogen production by electrolysis of water can be divided into alkaline electrolysis of water, proton exchange membrane electrolysis of water and solid oxide electrolysis of water for hydrogen production ${ }^{[3]}$. Among them, although the proton exchange membrane electrolyzed water is in the early stage of industrialization, it has a wide load range, fast response speed, small footprint, large cost reduction potential, and harmless electrolyte. It is a grid-friendly technology and is compatible with the development of renewable energy. Good sex, broad development prospects.

Table 4. Comparison of various technologies for hydrogen production by electrolysis of water

\begin{tabular}{|c|c|c|c|}
\hline & $\begin{array}{c}\text { Alkaline } \\
\text { water } \\
\text { electrolysis } \\
\text { hydrogen } \\
\text { production }\end{array}$ & \begin{tabular}{|c|} 
Proton \\
exchange \\
membrane \\
electrolysis of \\
water for \\
hydrogen \\
production
\end{tabular} & $\begin{array}{l}\text { Hydrogen } \\
\text { production } \\
\text { from solid } \\
\text { oxide } \\
\text { electrolysis of } \\
\text { water }\end{array}$ \\
\hline $\begin{array}{c}\text { Single mechanism } \\
\text { hydrogen capacity } \\
\left(\mathrm{m}^{3} / \mathrm{h}\right)\end{array}$ & About 1000 & About 400 & - \\
\hline \begin{tabular}{|c|} 
Power \\
consumption $(\mathrm{kw}$ \\
$\left.\mathrm{h} / \mathrm{Nm}^{3}\right)$
\end{tabular} & $4.5 \sim 5.5$ & $3.8 \sim 5.0$ & $2.6 \sim 3.6$ \\
\hline $\begin{array}{c}\text { Start and stop } \\
\text { speed }\end{array}$ & $\begin{array}{l}\text { Start and } \\
\text { stop faster }\end{array}$ & \begin{tabular}{|c|}
$\begin{array}{c}\text { Fast start and } \\
\text { stop }\end{array}$ \\
\end{tabular} & \begin{tabular}{|c|}
$\begin{array}{c}\text { Slow start and } \\
\text { stop }\end{array}$ \\
\end{tabular} \\
\hline $\begin{array}{l}\text { Power supply } \\
\text { stability } \\
\text { requirements } \\
\end{array}$ & $\begin{array}{c}\text { Stable power } \\
\text { supply }\end{array}$ & $\begin{array}{l}\text { Stable or } \\
\text { fluctuating }\end{array}$ & $\begin{array}{l}\text { Stable power } \\
\text { supply }\end{array}$ \\
\hline $\begin{array}{l}\text { System operation } \\
\text { and maintenance }\end{array}$ & \begin{tabular}{|c|} 
Corrosive \\
liquid, \\
complicated \\
operation \\
and \\
maintenance, \\
high cost \\
\end{tabular} & $\begin{array}{c}\text { No corrosive } \\
\text { liquid, simple } \\
\text { operation and } \\
\text { maintenance, } \\
\text { low cost }\end{array}$ & $\begin{array}{l}\text { Currently } \\
\text { focusing on } \\
\text { technical } \\
\text { research }\end{array}$ \\
\hline Safety & Poor & Better & Poor \\
\hline
\end{tabular}

\subsection{Analysis of operation mode of hydrogen production by water electrolysis}

For the hydrogen production scenario of water electrolysis, there are usually two modes of "source-side hydrogen production-hydrogen transmission-hydrogen" and "power. Transmission- load-side hydrogen production-hydrogen". The two modes are essentially hydrogen transmission and hydrogen production. Comparison of the advantages and disadvantages of power transmission.

Affected by multiple factors such as the costs and benefits of the entire process, barriers between industries, and the enthusiasm of power grid companies to participate, from the perspective of the entire process, the production, transmission and utilization of hydrogen energy in the region generally tend to adopt "source-side hydrogen production-hydrogen transmission- In the "use of hydrogen" model, the participation of grid companies is insufficient. However, according to calculations, for longdistance, large-scale hydrogen storage and transportation scenarios, compared to the "source-side hydrogen production-hydrogen transmission-hydrogen use" model, the "power transmission-load hydrogen productionhydrogen use" model is more efficient and safer.So it needs the strong participation of power grid companies etc.

\section{Conclusion and suggestion}

Aiming at the scenario of high-permeability renewable energy, this article analyzes the key links of the electricityhydrogen coupling and the main problems it faces from the whole link. The main conclusions and recommendations are as follows:

(1) There are many electricity-hydrogen coupling links, and hydrogen production by electrolysis of water is the key to electricity-hydrogen coupling. Currently, it is facing challenges such as high hydrogen production costs, immature technical routes, and restricted participation modes.

(2) Accelerate the development of key technologies such as hydrogen storage, fuel cell thermoelectric coupling, and hydrogen power generation systems, and focus on strengthening the layout of proton exchange membrane hydrogen production technology through joint research, and advance the deployment of hydrogen energy in electrolyzed water hydrogen production and distributed energy supply Demonstration applications in other fields.

(3) Incorporate renewable energy generation hydrogen production into the renewable energy consumption measures plan, and timely promote the application of wind power and photovoltaic power generation hydrogen production technologies in major renewable energy provinces, and explore new ways to solve renewable energy consumption.

(4) In the near future, we will adhere to the development route of hydrogen fuel cell vehicles based on commercial vehicles to ensure investment income. At the same time, we will accumulate hydrogen energy dispatching and supply and hydrogen refueling station operation experience, and in the medium and long term, we will steadily drive the development of passenger vehicles on demand.

\section{Acknowledgements}

This research was financially supported by State Grid Energy Research Institute Project "Research on production simulation model of park-level integrated energy system".

\section{References}

1. WANG Xiaochen, XU Shenzhi, LI Nan. The development of hydrogen fuel cell vehicles must not "increase without upgrading" [N]. China Energy News, 2019-05-20(028).

2. WANG Xiaochen, LI Nan. The road to hydrogen power generation: the road is hindered and long [J]. 
Economic Analysis of China Petroleum and Chemical Industry, 2019(02): 37-40.

3. WANG Xiaochen, JIN Yanming, ZHANG Jinfang, etc.A differentiated comprehensive benefit evaluation model considering the large-scale development of new energy sources[J]. China Electric Power, 2018, 51(10): 178-184.

4. DU Zexue. Green hydrogen may become the new favorite of the future hydrogen energy industry [N]. China Petrochemical News, 2020-07-07 (005).

5. Michael Frank Hordeski. Hydrogen \& Fuel Cells:Advances in Transportation and Power[M].River Publishers: 2020-12-17.

6. ZHAO Hongxue, LI Xiao, PANG Zhifei, etc. Analysis of the development status of hydrogen fuel cell vehicles[J]. Transportation Energy Conservation and Environmental Protection, 2020, 16(04): 11-15.

7. HU Jiancheng. Overview and prospects of the development of pure electric vehicles in my country [J]. South Agricultural Machinery, 2020, 51(22): 126127.

8. TAN Jing. Technical and economic comparison of hydrogen production by coal gasification, biomass gasification and hydrogen production by electrolysis [J]. Dongfang Electric Review, 2020, 34(03): 28-31.

9. LI Jing. Research on the influencing factors of hydrogen production by electrolysis of water[D]. Beijing Jianzhu University, 2020.

10. SU Jian. Multi-scale power prediction of photovoltaic power generation and evaluation of the ability to connect to the distribution network. Henan Province, State Grid Henan Electric Power Research Institute, 2017-04-20. 